Љиљана Ж. Пешикан-Љуштановић

Универзитет у Новом Саду

Филозофски факултет

Одсек за српску књижевност

joljilja@gmail.com

https://doi.org/10.18485/ai_gozik.2019.ch6

821.163.41.09:398

\title{
„ОЈ ЂЕВОЈКО, ВРЕЛА ВАРЕНИКО“- ОБРЕДНА ГОЗБА У УСМЕНОЈ ЛИРИЦИ: ОД ПАТОСА ДО КОМИЧКЕ ИНВЕРЗИЈЕ
}

Рад на примерима усмених лирских песама предвуковских бележења, из збирки Вука Стефановића Караџића и новијих записа, испитује заступљеност, распрострањеност и функцију гозбе / гошћења у усменој лирици. Примарни предмет истраживања биле су гозбе у обредним и обичајним песмама (пре свега коледарским и божићним), које окупљају и обједињавају колектив, функционишући, истовремено, и као успостављање везе са светим и уздарје вишој сили, али и оне у којима доминирају комичне инверзије обредне гозбе, претварајући богату, ретку, раскошну, егзотичну храну у својеврсну антихрану („од комарца ребарца, од мушице душице“). Сем тога разматрана је потенцијално иницијацијска функција хране (одгајање девојке / невесте, дозрелост за храну као сигнал сексуалне зрелости, формулативне љубавне понуде, тело-храна), метафоре које потичу из семантичког поља хране, као и поређења овог типа. Све

1 Истраживање на коме је заснован овај рад спроведено је у оквиру пројекта Аспекти идентитета и нихово обликоване у српској кюижевности (број 178005), који се, под руководством проф. др Горане Раичевић, спроводи на Одсеку за српску књижевност Филозофског факултета Универзитета у Новом Саду, уз финансијску помоћ Министарства просвете и науке Републике Србије. 
ово доприноси комплекснијем сагледавању поступака којима усмена лирска песма стилизује, сублимира и преобликује свакодневицу својих твораца и преносилаца.

Кључне речи: гозба, обред, обичај, хлеб, вино, жито, стока, пчеле, лоза, инверзија.

У нашој усменој лирици мотив обредне гозбе вишеструко је присутан ${ }^{2}$, али у њој има мало раблезијанског изобиља и телесног, чулног уживања у храни. Ове наше народске гозбе, као битан део обреда који окупља и обједињује заједницу - функционишући, истовремено, и као успостављање везе са светим - релативно ретко се одликују разноврсношћу и рафинираношћу хране. Битно за обредне гозбе у српској усменој лирици јесте учешће свију, изобиле хране и ситост за све коју оне доносе. Конкретна храна често и није предмет опевања. Тако свечарска песма „Кад се устаје у славу“, истиче моралну, духовну димензију славске вечере, без помињања конкретне хране:

А шта је љепше од славе Божје, И од вечере с правдом стечене. (СНП I: бр. 156. Подвукла Љ. П. Љ.)

Духовну димензију јела и пића истиче и раскошна слика кметова који славећи наздрављају у сложној, благословеној кући-гнезду. Сугестивно смењивање и концентрисање простора (пожњевено поље, слама у јаребичјем гнезду, слама на кућном крову, слава у кући,

2 У Речнику српскохрватског књижевног и народног језика гозба се дефинише као „обилан, тијепо припремлен обед, ручак, вечера у част гостију, свечаност, пријем; гошћене, чашћаване" (РСКНJ III: 422). 
златна трпеза) кулминира сликом славске „чаше бокушке“, којој је по врху бисер, а по дну злато:

Ој јаребичице, ој препеличице,

По пољу ходиш, по пољу плодиш,

Ражану кућу градиш.

На кући слама, у кући слава,

У слави златна трпеза;

Око ње редом кметови,

Пред њима чаше бокушке,

У њима вино канато,

По дну је злато,

А по врху бисер. [...]

(НУЛМС: бр. 79)

Атрибут канато уз вино може се различито тумачити. Према Речнику српскохрватског книжевног и народног језика (IX: 187-188), то би могло бити вино из глиненог суда - тестије, ћупа, крчага (стовне), али и вино праћено песмом, опевано ${ }^{3}$, или, шта ми се чини посебно значајним, вино стечено канатом - умереношћу, скромношћу, штедњом. ${ }^{4}$

Пандан овој са становишта хране неодређеној славској вечери, обележеној искључиво уложеним трудом и моралним квалитетом који он имплицира ${ }^{5}$, јесте гошћење конкретном храном („б’јела риба моруна“ из белог Дунава) која, пре свега, подразумева уједињавање колектива у напору да се достојно дочекају славски гости („добри гости у двору“):

3 Значење песма је прво наведено у Речнику за реч канат.

4 „Канат кућу држи.“ (РСКНJ IX: 187)

5 „едење је у најстаријем систему слика било нераздвојно повезано с радом. Долазило је на крају рада и борбе, било је њихова круна и тријумф. Рад је тријумфовао у једеньу" (Bahtin 1978: 298. Подвукао М. М. Б.). 
И скочио господар у дому,

И скупио до три слуге из двора.

Једног посла на то б’јело Дунавје,

Другог посла у ту гору зелену,

Трећег посла на то поље мезево 6 .

Кога посла на то б’јело Дунавје,

Он улови б’јелу рибу моруну.

Кога посла у ту гору зелену,

Он улови виторога јелена.

Кога посла на то равно мезево,

Он уфати златокос дјевојку

Госте части б'јелом рибом моруном,

И дарива виторогим јеленом,

Вино служи златокос' дјевојка.

(EP: 6p. 43)

Треба истаћи и то да се свето / гранично време празника, као искорак из свакодневице маркира „граничном храном“ - „б’јелом рибом моруном“ - која овакво одређење вишеструко имплицира, пре свега, природом која се моруни ${ }^{7}$ приписује у широко засведоченим народним веровањима. Име ове рибе моруна и његове варијанте у усменој књижевности: риба моруника / поморльива ${ }^{8}$, откривају народну етимологију - риба која мори, убија:

6 Према РСКНЈ, „бојно поље, бојиште, ратиште, поприште борбе“, односно „ледина, утрина, поље“ (XII: 324-325).

7 Моруна (лат. Huso huso) претежно је слатководна риба, која припада инфракласи штитоноша (лат. Chondrostei) и фамилији јесетри (лат. Acipenseridae). Реч је о највећој речној риби, која је пре изградње ђердапске бране силазила низ Дунав све до Смедерева. Насељава воде Каспијског језера, Црног и Азовског мора. Има је и у источном делу Средоземног мора и његовим сливовима. Велики је грабљивац и у њеној утроби налажене су велике рибе, па чак и птице (MEП II, 722; такође, <sr.wikipedia. org/sr/Моруна> 23. 8. 2013).

8 У песми из Малешева (МНП: 117) 
Чак и тамо где помињање моруне функционише као елеменат реалности (типичан за предање) ипак преовлађује логика nomen est omen. Тако, према предању забележеном у Смедереву у 20. веку, Јерина је у поплављеним лагумима смедеревске тврђаве вешала робље на ченгеле и остављала да га једу „оне рибе моруне“ (Милошевић-Ђорђевић 1997: 27). Апострофирање моруне би могло бити део реалног искуства приповедача, пошто се моруна одиста ловила у горњем току Дунава изнад Смедерева, а и грабљивост ове рибе могла је бити добро позната онима који су живели поред Дунава. Ипак, предање несумњиво садржи и снажан призвук нуминозног: у њему се, као доказ о демонској природи деспотице, користи и њен особени савез с рибом која мори“. (Пешикан-Љуштановић 2013: 193. Подвукла Љ. П. Љ.)

Сем тога, риба за славску трпезу уловљена је из белог Дунава, који „у народној традицији јесте и граница, и центар света [...] где се дешавају најважнији догађаји народног живота и пресецају сви путеви“ (CM: 168). ${ }^{9}$ Између граничне воде и рибе која у њој живи успоставља се, према веровањима, суштинска веза „што показује да то није само њено обитавалиште већ и део њене суштине, њена материјализација" (Беновска-С’бкова 1992: 56. Превела Љ. П. Љ.). Моруна, дакле, постаје, истовремено, и отеловљење сакрализованог простора у коме обитава. ${ }^{10}$

9 О томе види: Лома 2002: 37-40; Пешикан-Љуштановић 2002: 184-190; Detelić 2009: 449-521; CM: 168-169; Делић б.г.: [Рукопис одреднице за Српску енцииклопедију].

10 Сакрализација Дунава проистиче из чињенице да све граничне воде, оне које на различите начине, чувају и маркирају границу света живих и света мртвих (у митском поимању света: „Пут у друго царство пролази кроз змајеву губицу и преко воде као и кроз воду, и касније - по води“ - Prop 1990: 400), тиме, истовремено, постају свети и нечисти простори, који као места разграничења и додира поседују својства и једног и другог 
Маргиналност моруне ухваћене у граничној води, може, према широко распрострањеним веровањима, бити извор опасности, али и плодности:

Основна функција рибе из граничне воде, без обзира на именовања и без обзира на жанр у коме се јавља, остаје давање / враћање плодности. Ловљење и једење рибе, или њено изношење пред кума / краља, невесту, или на свадбену трпезу, опева се код свих Јужних Словена као део свадбеног обреда. (Пешикан-Љуштановић 2013: 194) $)^{11}$

Извор плодности могао би бити и додир оне која служи госте, златокосе девојке. Она је плен трећег ловца послатог „на то равно мезево“12. Ово упућује на потенцијални жанровски синкретизам ових песма, односно, на чињеницу да оне, док су живеле у усменом преношењу и употреби, нису биле строго жанровски кодиране, па се иста песма могла певати (и певала се, највероватније) у оквиру више различитих обреда, дакле и на слави и на свадби. Тако рибу (племениту, мостаркињу, малу, шестокрилу, златокрилу, златнокрилу, левокрилу, крилатицу, златну, перку, мостаркињу, племениту, моруну / морунику / поморливу, визу / везу / рису $\left.^{13}\right)$, која се током свадбе износи свадбену трпезу, најчешће лове сама невеста или младожења (нешто

света (Lič [Leach]1983: 123). Попут сваке границе, ове воде функционишу као „парадоксално место где они [овај и онај свет] међусобно опште“. (Елијаде [Mircea Eliade] 1986, 63)

11 Види: INP: br. 24; Димитријевић 1988: бр. 17; Богдановић б.г.: бр. 153; Јастребов 1886: стр. 165; Миладиновци 1962: бр. 522, 568; Верковиќ 1961: бр. 208; Стоин 1959: бр. 388; БНБ І: бр 190 и 191.

12 Варијантно, „Девојка ће под прстеном служити“. (СНП І: бр. 431)

13 Веза, виза и риса могу се двоструко тумачити, преко везе са грчким chrysos, златан, али и преко мађарског viza - моруна, док би веза и риса могли бити називи настали фонетским варирањем стране речи. Види: Klaić 1990, 1428. 
ређе), дакле они чланови заједнице чији је плодоносни потенцијал на врхунцу. На то упућује „под прстеном девојка“ (СНП I: бр. 431), али и златна коса девојке у варијанти из Ерлангенског рукописа, пошто су злату у традиционалним веровањима приписивани повећана моћ и плодоносни потенцијал.

Мрежа којом се чудесна риба лови често је сачињена од злата, сребра и бисера, али и од невестине косе (види Пешикан-Љуштановић 2013: 194). Сем тога, злато само по себи поседује повећану моћ, па и плодоносни потенцијал. Несумњива је, рецимо, веза која се, у свадбеним песмама, успоставља између злата и Сунца. Злато у овим песмама маркира и издваја исте хронотопе и бића као и Сунце: младожењин двор, невесту, девера, првенца, кума, сватове. Златом и сребром се нарочито обележавају простори окупљања сватова и управо „златни столи“ (СНП I: бр. 89, 113; СНП V: бр. 6, 44, 113, 115 и посуђе на њима - „златне гвантијере“ - бр. 109), дакле, простор сватовског гошћења. Ово се може тумачити као хипербола богатства / угледа / моћи младожењине породице, па и раскоши свадбене гозбе, али јесте, свакако, и заштитна, магијска издвојеност бојом и сјајем злата, које је у словенским веровањима „везано за симболику светлости, Сунца, Месеца“ (СМ: 204-205) и плодотворно. Да је злато плодоносни земаљски супститут Сунца ${ }^{14}$, указују и метафоре и поређења који се везују за невесту и поједине сватове (детаљније види Пешикан-Љуштановић 2017: 103-123).

Превасходно симболички карактер и наглашену духовну димензију има у усменој лирици и божићна трпеза, на коју се смештају често неодређена вечера

14 „Злато се најчешће асоцира са светлошћу, тачније оно је одраз Сунца..." (Раденковић 1996: 256) 
и вино: „Затекосмо где вечера / На трпези вино пије“ (СНП I: бр. 189; исто, СНП І: бр. 190); или хлеб и вино: „На трпези златна чаша, / Златна чаша и погача“ (СНП V: бр. 165. Подвукла Љ. П. Љ.). Вино и хлеб стављају се у овим песмама у исту раван као здравље, весеље и слога, па се тиме симболички подижу на ниво причешћа. Тако Божићева мајка шаље Божића, који носи здравље и весеље, слогу и „Трећу киту вина и шенице, / Да сте вазда п’јани и ситани“ (СНП V: бр. 184. Подвукла Љ. П. Љ. Варијанта, СНП V: бр. 185). У песми насловљеној „Три тичице с неба“ не помињу се пошиљалац и дародавац, али се јасно указује на природу примаоца и сврху међусобно изједначених дарова ${ }^{15}$ :

Прва носи гроздак од лозице:

Да се Срби понапију вина;

Друга носи класак од шенице,

Да Српкиње мијесе погаче;

Трећа носи брацког миробожја,

Да се Срби и грле и љубе,

У љубави један другом вика:

„Мир је Божи! е се Ристос роди“.

(CHП V: бp. 186)

Божићни дарови често и радо опевани у овим песмама разнородни су, али, по правилу, оним нематеријалним (здравље и весеље, мир, склад и слога, породична срећа и напредак) придружују се материјални дарови: изобиље у житу, лози, стоци и пчелама, што обезбеђује пуну трпезу: ${ }^{16}$

15 И Виноградова као „сижејне ситуације песама 'привредног' циклуса“ наводи: „птица буди домаћина и саопштава му вести о срећном плођењу стоке у његовом домаћинству“ и „соколи доносе плен свом домаћину“ (1982: 254).

16 У краљичкој песми (СНП I: бр. 174) на трпезу се уопште не смештају храна и пиће већ књиге, благо и свила, као добра која окупљају колектив (попове, трговце, терзије, али и браћу чија је трпеза). 
Море, Вели, чорбаџија,

Откад ти је подобрело?

„Од лани ми подобрело,

Жито ми се ородило,

Црне земље отежало;

Краве ми се истелиле,

Овце ми се изјагњиле,

Козе ми се искозиле.

Имам вино трогодишње,

И ракију петгодишњу;

Челе ми се изројиле,

Црни облак направиле.

Све је пуно и препуно,

Имам сина да услужи,

коледаре да причека.“

(Васиљевић 1960: бр.6)

Овом кругу песама, могу се придружити оне божићне песме у којима три Божићеве сестре варијантно обавештавају брата о изобиљу у житу, вину и стоци:

У Божића три миле сестрице:

Божо сестре дивно разређује,

Једну шаље да шеницу жање,

Другу шаље да виноград трга

Tрећу шаље да му јагњи овце.

Коју шаље да шеницу жање

Она сестра брату поручује:

„Дођи, Божо, дођи ми,брајане!

Добро ти је родила шеница,

Свако зрно по шиника дало;

Која ли је њива прележала,

Преложница сто шиника равно.“

Коју шаље да му лозу трга

Она сека брату поручује

„Дођи, Божо, дођи ми,брајане!

Добро ти је родила лозица

Свака лоза чабар вина дала.“

Коју шаље да му јагњи овце 
Она сека брату поручује „Дођи, Божо, дођи ми, брајане!

Добро су се изјагњиле овце,

Свака овца по јагњицу дала,

Уводница јањца и јагњицу.“

(СНП V, 180. Варијанте: бр. 181, 182, 183)

О чудесном напредовању стоке, пшенице, вина, домаћину који седи за празничном трпезом „глас доносе“ и коледари. На везу коледарског опхода са обиљем хране упућује и дедица / дед као вођа коледарске поворке, који, поред осталог ${ }^{17}$, изводи низ култних радњи које симболизују основне кућне послове: чишћење (прска водом по кући), припрему хране (вади печен хлеб из пећи, меша храну на огњишту), израду одеће (почиње да преде или плете). Сем тога, коледаре су у кућама даривали - најчешће храном, а ређе и новцем. Од скупљених дарова коледари су у појединим крајевима по завршетку опходњи спремали гозбу ${ }^{18}$, што као сегмент обреда указује на симболичку размену дара (коледари, као посредници између људског и божанског, доносе вести о рођењу „малог Бога“, чудесном напретку домаћиновог имања, и свеколикој плодности, благослову и берићету) и уздарја (домаћин их дарује храном $)^{19}$ :

\section{У Ивана, коледо, \\ Влашког бана, коледо, \\ Ту смо јели, коледо,}

17 Види: Виноградова 1982; Зечевић 2008: 72-115; Самарџија 2011: 561-589; Марјановић 2008; Торњански Брашњовић 2015: 389-401.

18 На њој су се певале и песме које садржином непосредно асоцирају на свадбене (СНП V: бр. 174).

19 У песмама је опис дарова које треба дати коледарима двострук: реалан, или бар реално могућ (пиће, стока, храна), или превасходно симболичан: девојка дорасла за удају, чоха нерезана, благо небројено, коњи нејахани, дакле, све ново, недирнуто и неначето, што асоцира на ново рођење и нови почетак. 
Дримску рибу, коледо,

Ту смо пили, коледо,

Очко вино, коледо

(Мијатовић 1907: 314. Наведено према Торњански 2015: 394)

Да храна која се дарује обредној поворци може бити и сасвим реалистично описана, сведочи у песму преточена молба прпоруша:

Даруј нама, стрико наша,

Оку брашна, стрико наша, Бублу масла, стрико наша, Рунце вуне, стрико наша, Један срчић, стрико наша, Два три јајца, стрико наша... (СНП V: бр. 158)

У контексту тог сложеног односа морало би се тумачити и привидно штеточинско понашање коледара, попут уништавања или крађе хране и пића. Павле Ровински у монографији Црна Гора у прошлости и садашности наводи три примера оваквог ритуално инверзног понашања:

Једном тако на Његушима весело друштво, дошавши у кућу где није било добре ватре, јер се није могло донијети дрва због великог снијега, побаца на огањ кобасице које су висиле изнад огњишта. У другој кући поломили су посуђе, клупе, разбили прозор, а да нису уопште били пијани. (Ровински 1994 III: 126)

Да је реч управо о ритуалној инверзији, указује и то што су, према сведочењу Ровинског, гости у кући Марка Миљанова, тадашњег управника Подгорице, узимали јела постављена на столу и ломили посуђе:

Украдене ствари даривали су другој кући. Храну су јели сами и давали другима које су сретали, нарочито сиро- 
масима. Нико се у таквим случајевима није љутио и није жалио штету, јер ће то по народном вјеровању све бити награђено од Бога. (Ровински 1994 III: 126)

Даривање украдене хране сиротињи сведочи о поштовању интегративне функције обредне гозбе, која пред лицем Бога дародавца и захваљујући њему обједињује око пуне трпезе све припаднике заједнице:

С печеницом поздрављаше

У том дому домаћина,

С ђевеницом полазника

И биране пријатеље;

А с погачом дариваше

Сиромахе и убоге.

(CHП V: бp. 192)

У овим песмама јасна је намера да се, с једне стране, од човеку надмоћних сила измоли помоћ и благослов, a с друге, да се, приписивањем обиља, имитативном магијом делује на постизање реалног благостања. Притом, храна и пиће, односно ситост и гасност ${ }^{20}$, као елементарни материјални дар, у овим песмама чувају чврсту везу с нематеријалном природом даривалаца, Бога / Божића / светитеља чији се празник прославља и доживљавају се као отеловљење њиховог благослова, који се може стећи само као награда и уздарје за примерено спровођење обреда. Да би Божић донео берићет и напредак било је неопходно да се дочекује слављем, игром и весељем и гозбом, па и претеривањем у јелу и пићу. ${ }^{21}$ Божићне и коледарске песме садрже својеврсна

20 Гасан (вероватно од гасити) у народним говорима означава напијеност, стање човека „који је утолио, угасио жеђ; супр. жедан“ (РСКНJ III: 203).

21 „О Божићу се објести и побљувати није никакове срамоте ('ако сам се опила, Божић ми је дошао’)“. (Караџић 1977: 35) 
упутства учесницима у обреду, попут позива на игру и весеље, који нису више само израз доброг расположења оних који славе већ и обавезан део обредног понашања:

Сви у колу весело, весело!

Хајд у коло, коледо, коледо!

(СНП V: 187)

Најисцрпнији опис пожељног празновања садрже песме о Божићу, који сам тражи одговарајућу част:

Божић зове сврх планине оне високе:

„Весел'те се, Србљи браћо, вријеме ви је.

Приправ'те ми све бадњаке свилом кићене,

А одаје и пенџере ловоричицом,

А иконе и столове маслиничицом,

Простирите шениц' сламу мјесто трпезе,

А по њојзи трпежњаке златом везене,

Наврћите добре овне на ражњевима,

Сијеците суво месо, а не мјерите,

А ложите крупна дрва, не цијепајте,

Приправ'те ми доста вина, рујна црвена,

И ракије лозоваче прве бокаре;

Ви невјесте и ђевојке коло ватајте,

Ви јунаци из пушака често мећите,

А ви старо и нејако, Бога молите.“

(СНП V: 191. Варијанте: СНП V: бр. 202, 203, 204)

Храна коју Божић захтева - пециво, суво месо, вино - и то без мере и штедљивог економисања (не мјерите, не иијепајте, приправ'те ми доста вина), није свакодневна, њоме се обележава празник или изузетан социјални стицај околности (долазак ретког госта). Зато претеривање у јелу и пићу, какво се јавља у божићним песмама, спада у облике обредног понашања намењеног подстицању плодности. Један број песма у ведрој комич- 
кој интонацији слави Божић као време велике мрсне гозбе. ${ }^{22}$ Огрнут сланином, закопчан петљама од кулена и кобасица „иде Божо планином“ (СНП V: бр. 212), доносећи привремено, али тим важније, изобиље симболизовано са „три златна ножића“ (СНП V: бр. 193), којима реже печеницу, ђевеницу (кобасицу), погачу (CHП V: бр. 192, 193, 195), или заоблицу, кобасицу, чесницу ${ }^{23}$ (CHП I: бр. 195), гибаницу, ђевеницу, заоблицу (СНП V: бр. 194), доносећи ситост онима који га дочекују:

О Божићу, брате,

Наједох се на те,

И по тебе дванди

Ма не као на те.

(CHП V: бр. 201. Варијанте, СНП V: бр. 199, 200)

Извођење и рецепција обредних песама имали су карактер јавне манифестације и веома важног колективног чина. Све док су опстајали, у овим обредима је учествовао цео колектив. Не само извођачи већ и примаоци, реципијенти, имају своју улогу у обреду и обред се без њих не може успешно и на општу корист

22 Божић који зове да га превезу преко воде, уместо одсутног домаћина који бере бадњак или доноси пециво, побраја као могуће водиче: старе бабе, невестице, девојчице, децу, а, у већини варијанти, помиње се страх да ће га оне које „масло варе“, омасити или опржити (види, СНП V: бр. 188, 189, 190).

23 Чесница је примарни обредни хлеб који се меси за Божић. Име чеснице потиче од речи чест - део, удео. Божићна чесница симболизује удео појединца у општој срећи и напретку. Сваком члану колектива даје се по парче. Месио је или претао сам домаћин или орач, поштујући низ обредних радњи, различитих од краја до краја, да би година била родна (понегде чесницу месе и прећу жене, често млађе). Чесница се као и други обредни хлебови меси с неначетом водом (водом захваћеном у праскозорје, коју нико пре водоноше није захватио). У чесницу су метани белези за овцу, пчеле, волове, плуг, семенке, новац. Детаљније види, СМ: 577-578. 
одвијати. Колективност овог обреда наглашена је и поименичним обраћањем свим члановима домаћинства: домаћину, домаћици, девојци, снахи. Штавише у обред се укључују и домаће животиње па постоје коледарске песме намењене волу, петлу, мачку, или лазаричке песме намењене пчелама, волу, мачку.

Магијски умножена и оптерећена драгоценим теретом, лазаричка пчела постаје део празничног славља, слутећи имање и изобиље:

Зададе се таман облак.

Неје облак но су пчеле.

На ножицу по ложицу,

На главицу каленицу.

Да благсовеш, зададе се,

Зададе се таман облак.

(Докмановић, Обредно певане за плодност: бр. 127. Види Докмановић 2004)

На Ускрс / Великден пчела од самога Бога доноси најаву будућег изобиља:

Долете челка од Бога,

Казује лето богато:

Великдан шарен, прешарен,

Ђурђевдан травком и шумом,

Петровдан белим јечменом.

(Јастребов: стр. 119) ${ }^{24}$

24 Или се, у лазаричкој песми с Косова хвали изобиљем:

[...] Хвали се пчела Подримка:

„Ја имам вино румено!“,

Хвали се пчела Косовка:

„Ја имам белу пченицу,

Да месим белу погачу!“

Бован, Обредне народне песме: бр. 172 
Од давнина неодвојив чинилац обреда посвећених култу плодности било је и еротско, као начело животворности које се још из прадавних времена непосредно везује са плодношћу земље, пошто се оплодња земље доводила у везу са светим браком - хијерогамијом и повезивала са људском плодношћу. Људско плођење се узимало као универзална парадигма плодности уопште, па се тако и еротско / плодоносно непосредно везивало за плодност земље и стоке:

Родило вам житно поље,

Винска гора па најбоље,

Једна овца по два шкопца,

А у планинка по два синка!

(Terseglav, Uskoška pesemska dediščina Bele krajine: br. 130)

У нашим обредним песмама ова непосредна нагонска еротичност углавном је потиснута и сублимирана од чулног у љубавно, али није сасвим ишчезла. Тако коледарска песма мачку садржи комичну слику раскалашних газдарица које набеђују мачка да је појео сир иако:

Саме су га обубале,

С калуђере под губере

И са власи

Под ораси.

(СНП V: бp. 172)

Јело и плођење се тако сугестивно обједињавају са прикривеним једењем „под губером“ и „под орасима“, са додатно табуираним љубавницима - власима и калуђерима - или се претапају са љубавном, лирски интонираном привлачношћу момака и девојака:

Огрејала јасна месечина,

Па се види до дела голема, 
Где девојће с'с јелење ору

Па си сеју белију пченицу.

Рало им је дрво јаворово,

А ост'н им змија ридовћиња.

Не ниче им белија пченица,

Нел им ниче смиље и ковиље.

Навали се смиље на ковиље

Кано момче на младо девојче.

(Кожељац, Јато голубато: бр. 41)

На иницијацијски аспекат хране указује блискост обредне гозбе свадбеној: коледари за трпезом певају свадбену песму, „ђевојка уходница“ је дар за њих, госте на слави служи „под прстеном девојка“. Обредни циклус године стално се укршта и спреже са животним циклусом појединца ${ }^{25}$, и ти пресеци су, уз остало, маркирани и храном / гозбом. Зачеће се тумачи претеривањем у јелу и симболизује се зобањем боба ${ }^{26}$, или, у шаљивој варијанти, „пуреног боба“:

[...],Твоја ћерца киселину јела, зато ти је шира него дуља.“

[...] „Твоја ћерца мутну воду пила, у води је стоногу попила, зато ти је шира него дуља.“ [...] Твоја ћериа пурен боб зобала, у бобу је жишка [по]зобала од жишка се чедо заметнуло зато ти је шира него дуља [...]“ (ЕР: бр. 165. Подвукла Љ. П. Љ.)

25 Види, Карановић 1996: 251-309.

26 Ој на делу на голему боб се зелени, А ко га је посејао те се зелени?

Ранко га је посејао те се зелени, Ружа га се назобала, срце је боли.

(СНП I: 6р. 679. Варијанта, СНП V: 6р. 270) 
И једна и друга варијанта песме могу се довести у везу с обредним посипањем невесте бобом, засведоченим на широком словенском простору (види, Плотникова 1996: 47-55; СМ: 31-32). Зобање боба, као метафора зачећа, кроз везу са сватовским обредима других словенских народа, добија значење конкретног ритуалног чина - посипања и залагања невесте зрњем махунарки. Исто тако, засведочена је, на широком словенском подручју, веза боба/пасуља са култом мртвих, што поново потврђује чврсту везу култа предака с плодношћу и изобиљем.

Одгајање девојке луксузном, пробраном храном и пићем, јавља се у свадбеним песмама као објашњење и узрок њене лепоте (што, такође, указује на непосредну везу хране и иницијације). У формулативном дијалогу невесте и девера храна којом се одгаја, подиже лепотица издваја се слашћу и опојношћу:

[...] шећер јела,

Шербет воду пила,

Шећерли се водом умивала.

(СНП I: бp. 85)

или:

С вечера ме вином умивала,

У по ноћи слатком медовином,

У прозорје млјеком и ракијом...

(СНП I: бр. 423. Варијанате, СНП V: бр. 7; 463)

И љубавне понуде које размењују заљубљени одликују се пробраношћу, слашћу, егзотичним пореклом и тешком доступношћу, саме собом оне сажимају тежак задатак за онога ко по целом социјалном простору (c мора, преко мора, из Мостара, из Стамбола) или у зах- 
тевно време (за росе, прије кукавице, прије прамалетја) мора сабрати ове понуде:

[...] и захтела је тешку понуду:

морскога грожђа, стамболске воде, жуте турунџе из прико мора. [...]

(ЕР: бр. 8. Подвукла Љ. П. Љ. $)^{27}$

О двосмисленом, еротизованом карактеру ових понуда јасно сведочи варијанта из Вукове збирке, насловљена Особити болесник (СНП I: бр. 481), где се упоредо с формулативним понудама „с мора смокве“, „шећер шербе“, понављају стихови: „А он неће с мора смокве да једе“ и „А он неће шећер шербе да пије“ и захтев за загрљајем („Већ он оће с једне руке на другу“, или пољупцем (Вук у напомени наводи: „Веће оће медна уста да љуби“).

И у шаљивим варијантама овог мотива, попут песме „А што су ми Карловкиње беле, румене?“ (ЕР: бр. 153 и СНП I: бр. 696), јасно је имплицирано да је еротска привлачност жене ${ }^{28}$ и на њој заснована моћ да манипулише мужем ${ }^{29}$ заснована на храни: „Вино пију, папар

27 Варијанте, Еp: 6р. 55; СНП I: 6р. 386, 387, 389, 390, 481, 737; СНП V: 6p. 288, 404,

28 Алитерацијом истакнут исказ „жено жива жељо“постоји у обе разматране варијанте.

29 Кад мужи орат иду, оне у крчму, а кад мужи дома иду, оне у кревет: "Јао мужу, леле мужу, глава ме боли.“ „Јао жено, жива жељо, да што ћу ти ја?“ „Доведи ми бездеткињу која не роди нек умеси погачицу трипут сијану, нек закоље шарку кокош која не носи и питлића копунића који не пива, донеси ми сахат меда сада вађена, донеси ми кондир вина сада точена.“ (ЕР: бр. 153) 
зобљу те су румене“ (ЕР: бр. 153) и еротском потенцијалу наговештеном хиперболисаном прождрљивошћу:

Пак уста болесница те да поруча:

од погаче не остаде него корица,

од кокоши и копуна не остаде него коштица,

а од вина не остаде него капљица,

а од меда не остаде него воштина.

„Јао жено, жива жељо, млого ти изиде!“

„Јао мужу, леле мужу, не подреци ${ }^{30}$ мене.“

Хуморном ресемантизацијом и дариваоца и примаоца „особитих понуда“ / болесника ${ }^{31}$, ова песма повезује озбиљне песме о љубавним понудама и храни леку и дару с пародично интонираним песмама ${ }^{32}$, у којима се ретка, пробрана, егзотична и луксузна храна замењује својеврсном антихраном, потискујући смехом потенцијални љубавни патос ${ }^{33}$ :

Оп цуп, цуп цуп, драгана,

Што ми ниси казала, Да мој драги болује, Да му носим понуде;

Од комарца ребарца,

Од мушице душице,

30 Подрећи значи урећи „немој да ме урекнеш“.

31 Орач који напорно ради док му жена проводи време у крчми, наивни, манипулацији подложни муж, несвестан женине праве природе, комично занет својом „живом жељом“ и лења, раскалашна, прождрљива и манипулативна жена, лажна болесница.

32 Види, Самарџија 2004.

33 [...] и захтела је тешку понуду:

морскога грожђа, стамболске воде, жуте турунџе из прико мора.

И отиде прилепи Павле

те он донесе тешке понуде... (ЕР: бр. 8) 
И од рака два крака,

И чашицу ракије,

Да се драги напије.

(СНП I: бр. 263)

Инверзија хране јавља се и у једном броју песама о моби. Уместо ручка који се не описује, али се наговештава особитом природом мобе („Косци косе војеводе Јанка / У ливади Краљевића Марка, / Златне косе, свилени откоси“) и девојке ручконоше („За ме су се завадили краљи, / Девет краља из девет земаља / И три цара из три Цариграда“ - ЗП: бр. 56), мобу, у карневалској инверзији, сачекује „торба / И у торби паучљива проја“ и „шугав јарац довече“ (СНП I: бр. 249) или чорба од „брава црвенога мрава“ (СНПр I: бр. 637). Ова комичка инверзија, у којој се потенцијално митској слици колективног прегалаштва супротставља хуморно интонирана, сиромашна и лоше храњена овоземаљска моба, могла је имати апотропејску функцију, смех и (ритуално?) нагрђивање могли су бити начин да се моба, домаћин и животно важни плодови њиховог труда заштите од злог ока и потенцијално непријатељских, угрожавајућих сила. Комиком изобличена слика гозбе пред апотропејске могла је имати и естетску функцију ${ }^{34}$ и „можда једнако важну, практичну, засновану на реалној људској потреби да се предах у послу потражи и нађе у смеху“ (Карановић - Пешикан-Љуштановић 1994: 35).

Сласт, опојност и моћ тела - хране имплицирају и формулативне метафоре и поређења које се везују за

34 „..Целовита песничка визија не може се у пуној зрелости и комплексности остварити искључиво у 'уозбиљеном' патетично подигнутом тону.“ (Карановић - Пешикан-Љуштановић 1994: 35) 
девојку (и, много ређе, момка), типа: медна уста / уста медена / пуна меда; шећер-уста, или:

Пољубих је једном доста;

Осташе ми медна уста,

Као да сам шећер ијо,

Али да сам шербет пио.

(Ровински III: бр. 50. Варијанта, СНП I: 547; Луча 1899/78: 337, бр. VI)

Исто важи и за оне песме које изједначавају женско тело и храну. То може чинити сама девојка, као лирски субјект, откривајући снажну еротску заинтересованост и самосвест младе жене дозреле за љубав:

Моје му очи ракија,

Моје му лице погача

А б’јело грло заслада...

(СНП I: бp. 576).

Тело-храну може сагледавати и млади мушкарац ${ }^{35}$, изједначавајући еротску жудњу са физичком глађу:

Ој дјевојко, врућа варенико,

Умријећу, не удробих у те!

(СНПр V: бр. 2)

То изједначавање две различите, али са становишта песме једнако битне глади доноси и уопштена, у трећем лицу изречена тврдња ${ }^{36}$ да „Ништа слађе нема до ђевојке, / То је право за јунака месо“ (СНП V. бр. 582).

35 За разлику од данашњег доба, усмена лирика претежно не препознаје „зрелу љубав“ (изузетак је, можда песма „Јанко Сибињанин и Јела удовица“ - СНП I: бр. 637), сем као разлог за подсмех.

36 Лирски субјекат остаје ван света песме. 
Истовремено, она, верујем, открива могућу иницијацијску димензију хране, односно везу хране и еротске дозрелости. Храна је, овако гледано, непосредно повезана са иницијацијским искушавањем младог мушкарца. Да је тако, сведоче три варијанте песме о сусрету момка / ђидије и непознате девојке. Све је ту ново, простор, девојка, њена реакција:

Прођох кроз гору, не знам кроз коју, сретох девојку, ал['] не знам коју, стадох јој на ногу, не знам на коју (ЕР: бр. 5. Подвукла Љ. П. Љ.),

односно,

Прођох кроз гору, не знам кроз коју;

Нађох дјевојку, не знам чија је;

Стадох на ногу, не знам на коју;

Стаде је вриска (не знам што јој је)...

(СНП I: бр. 535. Варијанта, СНП V: бр 579. Подвукла љ. П. Љ.)

Новина и потпуно незнање који прате сусрет непосредно подсећају на строгу тајност и изолованост некадашњих обреда прелаза, те на лиминалну неодређеност јунаковог статуса: „Обред се увијек проводио у дубини шуме или грмља, као строга тајна“ (Prop 1990: 91. Види, Ван Генеп 2005; Лома 2005: VII-XLI). Нова су и градативно дата искушења која девојка (као водич и помагач у иницијацији) поставља пред ђидију. Она су у све три варијанте идентична и дата истим редоследом. 

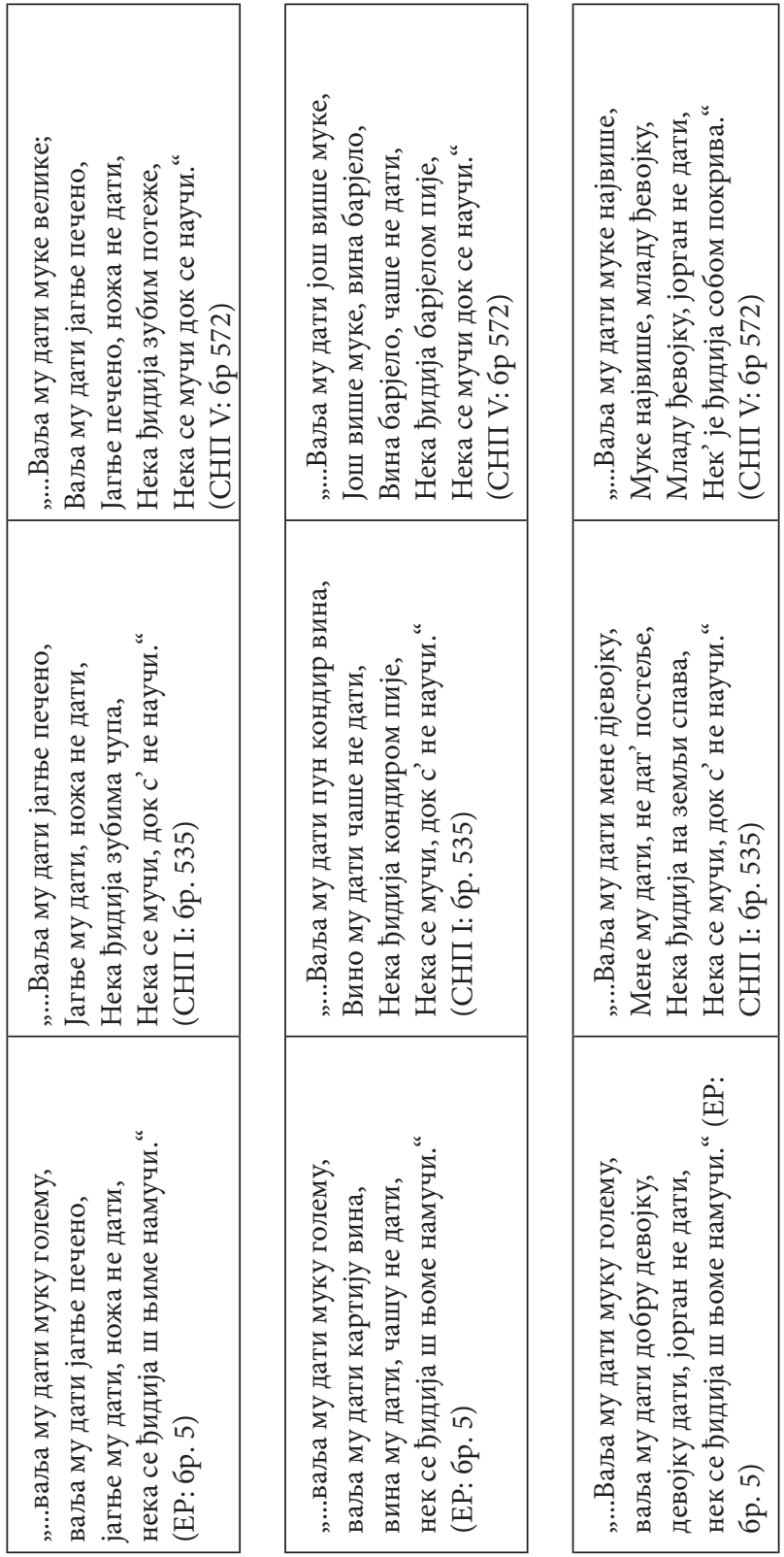
У све три варијанте најтеже искушење је девојка, а управо дораслост за храну и пиће и ритуално суочавање са елементарним, исконским растрзањем хране зубима, указује на дораслост мушкарца за љубавни чин као „муке највише“. Без обзира на то што се „момачке муке“ могу овде читати и као иронијско поигравање иницијацијском ситуацијом, несумњиво је да се еротска зрелост $^{37}$ и способност мушкарца за љубавни чин непосредно повезују са храном и пићем. Добар пример јесте песма о Кокану челебији (СНП I: 624, бр. [74]), која, без било каквог експлицитног исказа, садржи наглашен елеменат еротске двосмислености генерисан самим именом Кокан, снажном заинтересованошћу младих жена:

Пивај Маре, играј Анђелија, Не би ли вам ко у коло доша', Не би л' доша' Кокан од оваца...,

нежношћу дочека: „Но Кокане, мој драги окане 38 !“ и, пре свега, гаргантуовским изобиљем хране ${ }^{39}$ која је за њега само „чалабрчак“ пре ручка. ${ }^{40}$

Тако гледано, елементарна храна могла би упућивати на елементарну телесност. Сумбул удовица издваја се међу Новопазаркињама на теферичу храном коју

37 „Не може бити човјек доклен га жена не крсти.“ (Караџић 1977: 828)

38 Реч окан није засведочена у речничкој литератури и може се, претпостављам, тумачити или као позивање на очи (у значењу „дражи од очију“) или као изведеница од речи ока, онај ко може добро да попије (турцизам окадар значи пуно, много, обилато).

39 Кондир вина од дванаест око

И погача од три варићака,

И кајгана од стотине јаја...

(СНП I: 624, 6p.[74]).

40 На еротском подтексту могле би се заснивати и ругалице о прождрљивом зету у тазбини (СНП I: 6p. 707; СНП V: 6p. 591, 592. 
доноси: „свака носи питу и погачу, / Удовица јагње и баклаву“, али и у високо еротизованој ситуацији, када жене прелазе набујалу воду јашући младог мушкарца:

Од Мее су коња начиниле,

Од гаћа су седла начиниле,

Учкурима Меу зауздале.

Додир Сумбул удовице јасно се издваја по хиперболисаној, угрожавајућој ватрености:

Скочи Меи на плећа јуначка,

Кад су били насред воде ладне,

Цикну Мео као љута гуја:

Прогоре му на чефкен кошуља.

(СНП I: 614-615, 6p.[50])

Насупрот оствареној телесности која се једнако доказује у храни и сексу ${ }^{41}$, стоје песме о недораслом, престаром, или зимоморном мужу који „кад с’ облачи гуњину привлачи“ „када коси, рукавице носи“. Муж „зимомоља“ и не реагује на изобиље хране које му жена нуди ${ }^{42}$ с јасном мотивацијом „не би ли се мени примакнуо“:

41 Двосмислени двобој бабе и ђеда (CHП V: бр. 615) одлаже се тако до пролећа или „чак о јесени“: „Док наступи ново вино и овновина, / И погача поквасница и медовина“.

42 Опригам му шиник приганица, Чалабрчак док приспије ручак; Кад му станем сигурати ручак, Умијесим седам овсеница, И три котла урде и сурутке, Натоварим на магарца ручак, Одаженем њему на орање, Све изије, јад га задесио! (СНП I: 6р. 711) 
Ја с' примичем, а он се одмиче,

Примакни се, о невољо моја,

Што се жениш када жену нећеш...

(СНП V: бр. 600. Варијанта: СНП I: бр. 711)

Тело које прекомерно једе (најближе по духу и смислу Раблеовом свету) и његова неумерена, нарастајућа, неутољива прождрљивост слави се у оном мање записиваном и често потискиваном сегменту традиционалног свадбеног обреда у коме доминира комично-ругалачки, пародични, ласцивни, сексу и ждерању окренути аспект. Као симбол те нагонске глади и њеног задовољавања јавља се гузица. Невеста Дундара / Дундава, нема дарова:

Проведоше Дундару

Кроз зелену дубраву;

Питају је сватови:

„Кам ти, Дундо, датови?“ -

„Нисам прела ни ткала,

Нит'сам шила ни везла,

већ у млину сидила,

Колачиће кувала,

У гузицу мећала!“

(СНПр I: бр. 311. Варијанте: СНП I: бр. 708; СНП V: бр. 627; СНПр I: бp.312, 313, 314) ${ }^{43}$

Стражњица / гузица ${ }^{44}$ постаје понор који прождире невестинске дарове, иако су они у свечано уозбиљеном аспекту обреда неопходан део свадбе и симбол сложених односа размене који се њоме успостављају. Као дар нуди се овде невестина моћна, тријумфална телесност

43 Детаљније о овоме, види: Карановић - Јокић 2009.

44 Обични сватови „без чина“, без додељене улоге у обреду, зову се, и иначе, набигузице. 
и њена доказана плодност. ${ }^{45}$ Тиме се остварује јединство духовног и материјалног, целовитост и обједињеност древног концепта света.

Микрокосмос љуског тела, поделом на доњу и горњу сферу (испод паса и изнад паса), чисто и нечисто, мисао и нагон, понавља структуру макрокосмоса и његову поделу на горње, небеско, божанско, бесмртно, светло, и доње, земаљско, људско, смртно и кално. „Из главе“ излази поредак, норма. Зинуло дупе, насупрот томе, оличава голу, незаситу глад, тамни, нечисти, смрадни свет нагонског. Тако погузије, набигузице, гулозни, облогузије, згузанагузановићке својим незаситим апетитом - за храну или секс, свеједно - нагризају владавину разума, показујући своју суштинску субверзивност. - За разлику од човека модерног доба ${ }^{46}$,

45 Упоредо са гаргантуовским сатирањем хране: „два овна испод звона“, „дви овце јаловице“, „четири овсенице“, невеста рађа дете у кога је „пуно отац“:

До двадесет Которана, И тридесет Имоћана, И два драга испод града, И два мила иза млина, И два попа иза плота, И Илија синџирлија, И Иване нахеркапане...

46 Лаза Костић, у Спомену на Руварияа пева:

Алфа је глава, - алфа, то је ум, почетак свега, душин неимар, што у њој зида будућности сјај; а омега, јест, омега је кук, срамота, трбух, лакомост и блуд, зидара умног вечни рушитруд то омега је свему, свему крај.

Ипак, и хришћанске културе знају да се не може „утећи од гузице“ - време карневала обрће ствари наглавце. Власт преузима доњи део тела и свет се, попут пешчаног сата, окреће наглавце. Власт разума се збацује, а учесник карневала, док славље траје, „мисли гузицом“, иживљавајући нагонско и поново остварујући суштинско јединство властите људскости (види Bahtin 1978). 
некадашњи човек поседује и дубоку свест о јединству ова два пола властите људскости. Зато се у његовој обредној пракси даје простор и једном и другом. Тако се и стражњица, као моћан утук против демонских сила и урока, укључује у обред. Дупетом се, рецимо, затварају врата када се иде у просидбу, да би се тако затворила уста душманина ако клевећу момка. ${ }^{47}$

Дајући допринос целовитости традиционалног света, храна, с једне стране, улази у усмену лирику, обредну, обичајну, љубавну као релативно недиференцирано, жељено изобиље и берићет. Оваква храна је мање везана за своју појавну, чулно телесну димензију и задовољење телесне глади, а више се јавља као извор плодности и симбол духовних вредности: заједништва и солидарности, односа према вишој сили. С друге стране, храна и једење у усменој лирици јесу и израз тријумфа телесности, еротске дозрелости (или незрелости јединке), што имплицира комичне / инвертне / пародијске / гротескне представе о храни и онима који је једу. Управо зато, гозба у усменој лирици и гозба усмене лирике открива се као сложен и разуђен поетски код чије комплексно истраживање тек предстоји.

\section{Извори и литература}

Елијаде, Мирча. Свето и профано. С француског превео Зоран Стојановић. Предговор („Архајски човек и мит”) написао Сретен Марић. Нови Сад: Књижевна заједница Новог Сада, 1986. Штампано.

47 За дупе се ваља ухватити када нам неко жели зло. Задизањем сукње жене су терале град. И дан данас деца пљескањем по дупету исказују ниподаштавање, или терање противника. 
Беновска-С’бкова, Милена. Змејат в б'лгарския фолклор. Софија: Издателство на Б’лгарската академија на науките, 1992. (Извршена транслитерација у српску ћирилицу.) Штампано.

БНБ I - Б’лгарски народни балади и песни с митически и легендарни мотиви. Лилјана Богданова и др. Част 1, Софија: Б’лгарската академија на науките, 1993. (Извршена транслитерација у српску ћирилицу.) Штампано.

Бован, Владимир. Обредне народне песме. Студентски записи српских народних умотворина на Косову и Метохији. Приштина - Бања Лука - Исток: Бесједа, Дом културе „Свети Сава”, 2000. Штампано.

Богдановић, Недељко. Свадбене песме свртишког краја. Сврљиг: Етно-културолошка радионица. Б. г. Штампано. Ван Генеп, Арнолд. Обреди прелаза. Систематско изучаваюе ритуала. Са француског превела Јелена Лома. Српско издање приредио Александар Лома. Београд: СКЗ, 2005. Штампано.

Васиљевић, Миодраг А. Народне мелодије лесковачког краја. Београд: Музиколошки институт Српске академије наука, 1960. Штампано.

Верковић, Стефан Н. Македонски народни песни. Редакција и предговор Кирил Пенушлиски. Скопје: Кочо Рацин, 1961. (Извршена транслитерација у српску ћирилицу.) Штампано.

Виноградова, Лјудмила Николаевна. Зимнјаја календарнаја поезија западних и восточних славјан. Генезис и типологија колјадованија. Москва: Издател'ство „Наука”, 1982. (Извршена транслитерација у српску ћирилицу.) Штампано.

Делић, Лидија. „Дунав (Дунаво, Дунај, Дунава)“. У рукопису. Димитријевић, Сергије. „Народне песме лесковачког краја“. Лесковачки зборник. Св. 2. Књ. XXVIII/1988. Штампано. Докмановић, Јасминка. Обредно певане за плодност (лазариuе) у јужној Србији. Музички талас, број 27/2000. Штампано.

Докмановић, Јасминка. Обредно певане за плодност и негово инструментално окружене у југоисточној Србији [Звучни снимак]. Песме: лазаричке, за „премуз“, јеремијачке, 
додолске, крстоношке, жетварске. The Ritual singing for fertility and its instrumental environment in the South-East Serbia. Lazaritse songs, singing for premuz, for yeremiya day, for rain (dodole and krstonoshe), harvest. Београд: Clio, 2004. Штампано.

ЕР - Ерлангенски рукопис старих српскохрватских народних песама. Приредио Герхард Геземан. Београд - Ср. Карловци 1925: Издање приређивача. Веб. 22. 11. 2018.

Зечевић, Слободан. „Коледа. Опис и распрострањеност“. Српска етномитологија. Приредили Бојан Јовановић, Божидар Зечевић. Београд: Службени гласник, 2008: 72-115. Штампано.

ЗП - Златна пјена од мора. Народне пјесме Срба у Хрватској. Приредио Здравко Крстановић. Б.м.: Пројекат Растко Библиотеке српске културе на Интернету. Веб. 23. 11. 2018. Јастребов, И[ван] С[тепанович]. Обичаи и песни турецких Сербов (в Призрене, Ипеке, Мораве и Дибре). Из путевих записок. С. Петерсбург: [издање аутора] 1886. (Извршена транслитерација у српску ћирилицу.) Штампано.

Карановић, Зоја - Љиљана Пешикан-Љуштановић. Послови и дани српске песничке традииије. Нови Сад: Светови, 1994. Штампано.

Карановић, Зоја. „Архајски корени српске усмене лирске поезије“. Антологија српске тирске усмене поезије. Приредила Зоја Карановић. Нови Сад: Светови, 1996: 251-309. Карановић, Зоја - Јасмина Јокић. Смеховно и еротско у српској народној култури и поезији. Нови Сад: Филозофски факултет, 2009. Штампано.

Караџић, Вук Стефановић. Српски рјечник истумачен немачкијем и латинскијем ријечима. Скупио га и на свијет издао Вук Стеф. Караџић. У Бечу 1852. Навођено према: Београд: Нолит, 1977.

Кожељац, Јато голубато - Љубиша Рајковић Кожељац. Јато голубато. Лирске народне песме из источне Србије. Зајечар: Културно просветна заједница, 1991. Штампано.

Лома, Александар. Пракосово: словенски и индоевропски корени српске епике Љубинко Раденковић (ур.). Београд: Балканолошки институт САНУ, 2002. Штампано. 
Лома, Александар. „Мистерија прага. Обреди прелаза Арнолда ван Генепа на прагу свога другог столећа“. Предговор књизи: Арнолд ван Генеп, Обреди прелаза. Систематско изучавағе ритуала. VII-XLI. Штампано.

Луча 1899/7-8 - „Српске народне женске пјесме“. Луча. Св. 7-8/1899: 336-337. Штампано.

Марјановић, Весна. Маске, маскираюе и ритуали у Србији. Београд: Чигоја штампа, Етнографски музеј, 2008. Штампано.

МЕП II - Мала енииклопедија Просвета: опита енциклопедија. Књ. 2 (К - Пн). Београд: Просвета. 1986. Штампано. Миладиновци. Зборник 1861-1961, Скопје: Кочо Рацин, 1962. Штампано.

Милошевић-Ђорђевић, Нада. Од како се земља охладила. Прозни облиии српске народне книжевности и мале фолклорне форме. Београд: Завод за уџбенике и наставна средства, 1997. Штампано.

МНП - Малешевски народни песни. Збирка на Славко Костић. Скопје: Институт за македонски језик, 1959. (Извршена транслитерација у српску ћирилицу.) Штампано. НУЛМС - Народне умотворине у Летопису Матице српске. Приредили Марија Клеут, Миодраг Матицки, Снежана Самарџија, Милорад Радевић. Нови Сад - Београд: Матица српска, Институт за књижевност и уметност, 2003. Штампано.

Пешикан-Љуштановић, Љиљана. „Поморљива риба из граничне воде“. Aquatica: кюижевност, култура. Мирјана Детелић, Лидија Делић (ур.). Београд: Балканолошки институт САНУ, 2013. [191]-202. Штампано.

Пешикан-Љуштановић, Љиљана. Змај Деспот Вук - мит, историја, песма. Нови Сад: Матица српска, 2002. Штампано.

Пешикан-Љуштановић, Љиљана. Сунце, месец и звезде у свадбеним песмама Вукове збирке. Заступљеност и значење. Il SoleLuna presso gli slavi meridionali. Vol. I. A cura di Ljiljana Banjanin, Persida Lazarević Di Giacomo, Sanja Roić, Svetlana Šeatović. Alessandria: Edizioni dell'Orso. Сунце, месец и звезде у свадбеним песмама Вукове збирке. Заступљеност 
и значење. Il SoleLuna presso gli slavi meridionali. Vol. I. A cura di Ljiljana Banjanin, Persida Lazarević Di Giacomo, Sanja Roić, Svetlana Šeatović. Alessandria 2017: Edizioni dell’Orso. 2017: 103-123. Штампано.

Плотникова, Ана А. „Боби, фасол' и горох в символике рожденија и смерти“. Кодови словенских култура. Год. 1. Бр. 1/1996. 47-55. (Извршена транслитерација у српску ћирилицу.) Штампано.

Раденковић, Љубинко. Симболика света у народној магији Јужних Словена. Ниш - Београд: Просвета - Балканолошки институт САНУ, 1996. Штампано.

Ровински, Павел Аполонович. Црна Гора у прошлости и садашғости. Том III. Етнографија - книжевност и језик. Превела с руског Видосава Стојановић. Редактор превода др Александар Терзић. Цетиње - Нови Сад: Издавачки центар „Цетиње“, Централна народна библиотека „Бурђе Црнојевић“, Издавачка књижарница Зорана Стојановића, 1994. Штампано.

РСКНЈ III - Речник српскохрватског книжевног и народног језика. Књ. 3. Вразнути - гушчурина. [Приредила] Српска академија наука и уметности. Београд: Институт за српскохрватски језик, 1965. Штампано.

РСКНЈ IX - Речник српскохрватског книжевног и народног језика. Књ. 9. Јургет - колитва. [Приредила] Српска академија наука и уметности. Београд: Институт за српскохрватски језик, 1975. Штампано.

РСКНЈ XII - Речник српскохрватског књижевног и народног језика. Књ. 12. Маквен - мозурица. [Приредила] Српска академија наука и уметности. Београд: Институт за српскохрватски језик, 1984. Штампано.

Самарџија, Снежана. Пародија у усменој књижевности. Београд: Народна књига - Алфа. 2004. Штампано.

Самарџија, Снежана. „Од жртве до пешкеша. Функције дарова и даривања у усменој књижевности.“ Жива реч. Зборник у част проф. др Наде Милошевић Ђорђевић. Београд: Балканолошки институт САНУ. 2011: 561-589. Штампано. 
СМ - Словенска митологија: енциклопедијски речник. Приредили С. Толстој и Љ. Раденковић. Београд: Zepter Book World. 2001. Штампано.

СНП I - Српске народне пјесме. Скупио их и на свијет издао Вук Стеф. Караџић. Кюига прва, у којој су различне женске пјесме. Беч 1841. Навођено према: Сабрана дела Вука Караџића. Приредио Владан Недић. Београд: Просвета, 1975. Штампано.

СНП V - Српске народне пјесме. Скупио их и на свијет издао Вук Стеф. Караџић. Књига пета у којој су различне женске пјесме. Приредио Љуба Стојановић. Београд: Државно издање, 1898. Штампано.

СНПр I - Српске народне пјесме из необјавъених рукописа Вука Стеф. Каращића. Књига прва. Различне женске пјесме. Приредили Живомир Младеновић и Владан Недић. Београд: Српска академија наука и уметности, 1973. Штампано.

СНПр V - Српске народне пјесме из необјавлених рукописа Вука Стеф. Каращића. Књига пета. Особите пјесме и поскочище. Приредили Живомир Младеновић и Владан Недић. Београд: Српска академија наука и уметности, 1974. Штампано.

Стоин, Васил. Народни песни от западните покрајнини. Софија: Институт за музика - Б’лгарска Академија на Науките, 1959. (Извршена транслитерација у српску ћирилицу.) Штампано.

Торњански Брашњовић, Светлана. „Даривање коледарске поворке и песме које се изводе тим поводом“. Книжевност и језик. Часопис Друштва за српскохрватски језик и кюижевност. Год. 62. Бр. 3-4/2015: 389-401. Штампано.

Bahtin, Mihail Mihajlovič. Stvaralaštvo Fransoa Rablea i narodna kultura srednjeg veka i renesanse. Preveli Ivan Šop i Tihomir Vučković. Beograd: Nolit, 1978. Štampano.

Detelić, Mirjana. „Epska hidronimija“. Onomatološki prilozi. XIX-XX/2009: 449-521. Štampano.

INP - Istarske narodne pjesme. Opatija: Istarska književna zadruga, 1924. Štampano. 
Klaić, Bratoljub. Rječnik stranih riječi. Tuđice i posuđenice. Priredio Željko Klaić. Zagreb: Nakladni zavod MH, 1990.

Lič, Edmund. Kultura i komunikacija. Logika povezivanja simbola. Uvod u primenu strukturalističke analize u socijalnoj antropologiji. Preveo s engleskog Boris Hlebec. Beograd: Prosveta, 1983. Štampano.

Prop, Vladimir Jakovljevič. Historijski korijeni bajke. Prevela Vida Flaker. Sarajevo: Svjetlost, 1990. Štampano.

Terseglav, Marko. Uskoška pesemska dediščina Bele krajine. Ljubljana: Znanstvenoraziskovalni center SAZU, 1996. Štampano.

Ljiljana Ž. Pešikan-Ljuštanović

\author{
„OJ ĐEVOKO, VRELA VARENIKO“ \\ THE RITUAL FEAST IN ORAL LYRICS: \\ FROM PATHOS TO COMIC INVERSION
}

This work would examine oral lyrical poems created before, during and after the recording of Vuk Karadžić, the presence, distribution and function of the feast in the oral lyric. The primary, but not the only subject of research, would be feasts in ritual and customary poems that gather and unite the collective, functioning at the same time, as well as establishing a connection with the holy and gift to the higher power. In addition, we will speak about food metaphors in the oral lyricism, as well as comparisons of this type, formulative love offerings and, in particular, comical inversions in which a rare, luxurious, exotic food turns into a kind of anti-food. In addition, the potential initiation function of food (girl / bride rearing, maturity for food as a signal of sexual maturity, formulaic love offers, body-food), metaphors derived from the semantic field of food, and comparisons of this type.

All of this contribute to a more complex examination of the processes by which the oral lyrical poem stylizes, sublimates and transforms the everyday life of its creators and transmitters. 